\title{
BREAKING AWAY FROM EGOCENTRISM. POSTHUMANISM AS A WAY OF CONTEMPLATING NON-HUMAN MATTERS ON STAGE
}

\author{
MILO JURÁNI \\ Theatre Faculty of the Academy of Performing Arts, Bratislava, Slovakia
}

\begin{abstract}
Anthropocentrism is one of the key concepts associated with a broken relationship between humans, or human society, and the natural world. An excessive focus on the human is among the debated shortcomings that exacerbates environmental crises. In environmental humanities, it is especially addressed by environmental ethics. Anthropocentrism as a problem also steps into the expert debate on environmental or ecologically oriented theatre and performing arts. These media are historically understood as media focused on the human, human society, human relationships, events, and history. In the presented study, some of the starting points of posthumanist philosophy that could enrich contemporary theories of theatre and performance art are considered, to help broaden their scope of attention to a group of specific works. These are various works of art confronting anthropocentrism, or using approaches that mediate non-anthropocentric and post-anthropocentric knowledge. From a theatrological point of view, they are identified in the framework of works which Hans-Thies Lehmann calls postdramatic theatre, however, from the perspective of philosophy, they are in a certain relation with the essential ideas of posthumanism as defined by Francesca Ferrando and Rosi Braidotti, to give an example. The study's ambition is to provide fertile ground for a continued and more thorough perspective of a group of works that fall under performing arts (drama, theatre play, performance art), which primarily deal with the relationship between the human and nonhuman nature and offer unconventional ways of representing non-human nature or reflections on the relationship between non-human nature and the human.
\end{abstract}

Keywords: anthropocentrism, posthumanism, postdramatic theatre, performance art, non-human, environmental problems

Anthropocentrism is one of the key concepts that environmental ethics has been addressing since the 1980s. At present, in the context of the debate on climate change, global warming, and other environmental crises, as well as the contemplations over defining the current geological period ${ }^{1}$, it becomes one of the central issues in scientific disciplines which have so far been dealing with it only marginally. In addition to the natural sciences, philosophical, philological sciences as well as culture and art sciences or various crosscutting, interdisciplinary sciences are becoming increasingly interested in the issue. In her study on anthropocentrism, the philosopher Onora O'Neill states: "A common criticism of anthropocentrist positions in ethics is that they all incorporate what has come to be called speciesism. The term speciesism, which

${ }^{1}$ The best known and the most widely covered term by the media is Anthropocene, i.e. a geological epoch during which human agency has had a significant impact on climate and the natural environment. Environmentalist Eugene Stoermer and atmospheric chemist Paul J. Crutzen defined and popularised it for the first time in 2000 in a newsletter of the International Geosphere-Biosphere Programme. See 'The Anthropocene'. In Global Change Newsletter, 2000, Issue 41, pp. 17 - 18. 
was coined by analogue with terms such as racism or chauvinism, is usually used as a label for unjustified preference for the human species. The problem with any form of speciesism, critics complain, is that it accords humans moral standing, but unjustifiably accords animals or other species no, or only lesser, standing." ${ }^{2}$ From what has been said above, it is clear that focusing on "anthropos" leads to the singling out of human society and positioning it above the laws of the natural world, thus leaving various devastating impacts behind. This, for example, leads to the humanisation and use of natural resources and to the legitimisation of its exploitation, despite the fact that humanity has attached very concrete names to the consequences of such action human-caused climate change, sixth mass extinction, the plundering of ecosystems. The issue of anthropocentrism has become part of a professional debate on environmental, or ecologically oriented art. The practice and theory of performance arts and theatre, intermedia, and aesthetics also deals with the issue exhaustively.

\section{Toward Anthropocentrism}

Hence, anthropocentrism represents human domination of the Earth. It is a human-oriented interpretation of natural, religious matters, which emphasises the separation of humans from non-human nature, the supremacy of the human over all creation, and also the understanding of matter as a source to satisfy human needs. By focusing on humans, it strengthens the values associated with the destruction of the planet as well as with an excessive use of matter (the so-called natural resources) found on the planet. " "As an ethical view anthropocentrism refers to the explicitly stated or implied claim that only human beings have intrinsic value; all other natural beings and things have only instrumental value, and human interests thus always trump the interests of nonhumans and the environment." ${ }^{4}$

The beginning of this utilitarian function of the Earth goes long back in time, but in connection with today's environmental situation, it has its time-space roots in the period of the industrial revolution in the western countries of the global north. Previously, during a longer period of the known human history, the extent of production was significantly lower. Environmentalist Ben Minter gives the following reasons under the heading Anthropocentrism in the Encyclopedia of Environmental Ethics and Philosophy: "After the industrial revolution, science and technology progressed in leaps and bounds. The rapid development of productive forces enabled economic development to gradually transition from the agricultural era, the industrial era, the electronic age, and to today's information age." 5

When regarded from the perspective of the history of thinking and human cognition, the concept of human dominance over non-human nature is not limited to the most recent period of history. Anthropocentrism is at the very roots of Western religion, philosophy, and culture. This follows from the teachings of Western philoso-

${ }^{2}$ O'NEILL, O. Environmental Values, Anthropocentrism and Speciesism. In BOYLAN, M. Environmental Ethics. Oxford : WILEY Blackwell, p. 123.

${ }^{3}$ See MALINA, J. et al. Antropologický slovník. BRNO : Akademické nakladatelství CERM, 2009, p. 131.

${ }^{4}$ MINTEER, B. A. Anthropocentrism. In CALLICOTT, J. B., FRODEMAN, R. (ed.). Encyclopedia of Environmental Ethics and Philosophy (Vol. 1). USA : Macmillan Reference, p. 58.

${ }^{5}$ ZENG, F. Introduction to Ecological Aesthetics. Singapore : Springer Nature, 2019, p. 22. 
phers of antiquity, such as Aristotle and Plato. One may also mention the Christian starting points, according to which man is the master of creation ${ }^{6}$, which is criticised by Lynn White Jr., and also the teachings of René Descartes or Kantian philosophy, modern times philosophy connected with Cartesianism focused on human reason and the unlimited potential of the human species, the understanding of nature as an object of research, and many others.

A symbolic singling out of the human from the set of the world also infiltrated the Western natural sciences, in which it had been enjoying a unique position from the Renaissance onwards. This has been repeatedly pointed out since antiquity through various representations of the image of the human in nature as the Great Chain of Being ${ }^{7}$ by which Western philosophy repeatedly emphasised the interconnectedness of all living and non-living things, but at the same time insisted on Homo sapiens being at the top of the world order (just below celestial beings) ${ }^{8}$ and it therefore enjoyed a privileged position.

\section{Theatre and Performance Art as an Anti-ecological Medium}

In her study "There Must be a Lot of Fish in That Lake": Toward an Ecological Theater" published in 1994, Una Chaudhuri, pioneer of ecocriticism in theatre, professor of literature and drama and of environmental studies, points out that among the reasons for drama and theatre being anti-ecological is their focus on the human or human society. In the Renaissance and in the periods following the Industrial Revolution, i.e. at the time of the formation of modern society, in drama and theatre, the natural environment (and what makes it up) was belittled to a mere background for the actions of human characters. Nature has become a metaphor for human matters. In the works of naturalists (Henrik Ibsen, August Strindberg, Gerhart Hauptmann, Anton Pavlovich Chekhov), the environment is literally a co-creator of the situation (The Cherry Orchard, Uncle Vanya, An Enemy of the People), it is among the prominent elements of the plotline, it even impacts our feeling of life and determines the social status and conflicts of characters. Nevertheless, the environment has only a trivial role to co-create the image of humans through a network of human social ties. ${ }^{10}$ Both naturalists and realists represented interpersonal relations and "thrust the non-human world into the shadows, from which it emerged in the ghostlike form of strangely menacing - yet inanimate - objects."11

${ }^{6}$ As stated in the Holy Bible: "God blessed them and said to them, 'Be fruitful and multiply, and fill the earth and subdue it; rule over the fish of the sea and the birds of the air and every creature that crawls upon the earth'". See The First Book of Moses - Genesis. [online]. [cit. 24 March 2020]. Available at: http://biblia.ssv. sk/biblia/kniha/genezis-prva-kniha-mojzisova/kapitola/1.xhtml\#ct.

${ }^{7}$ The Great Chain of Being or scala naturae is a classical conception of the metaphysical order of the universe in which all beings from the most basic up to the very highest and most perfect being (nature or god) on the top are hierarchically linked to form one interconnected whole. Its roots go back to antiquity and it was shaped in the medieval period through the works of Neoplatonists and in various forms it continues until the present.

${ }^{8}$ See WUKETITS, F. M. Př́rodní katastrofa jménem člověk (Naturkatastrophe Mensch. Evolution ohne Fortschritt). Praha : Granit, 2006, p. 26.

${ }^{9}$ CHAUDHURI, U. "There Must Be a Lot of Fish in That Lake": Toward an Ecological Theater. In Theater, 1994, Vol. 25, Issue 1, pp. $23-31$.

${ }^{10}$ Ibid., p. 24.

${ }^{11}$ Ibid. 
In the above study, Una Chaudhuri quoted Alan Read's prescription for theatre: "What is needed is not the ignorance of nature but more acute definition between political, ethical and creative processes and living within nature, which inevitably is a transformation of nature."12

Dramatic theatre which offers human representation using sign systems specific to humans and communicates by employing the voice and the body of a human actor, is conventionally understood as a form which - as stated by the Czech theatrologist Zdeněk Hořínek - "performs a human next to a human, a human together with a human, and of course, a human against a human."13 The same situation applies to performance art. In her essential handbook Performance Art theoretist Rose Lee Goldberg writes that "... performance defies precise or easy definition beyond the simple declaration that it is live art by artist..."14 and continues by stating "... live presence of the artist, and the focus on the artist body, became central to notions of 'the real.'"15 According to German theatrologist Erika Fischer-Lichte "nature of performance dictates that artists-in-action cannot be severed from their material. They make their 'artwork' from a highly peculiar, even wilful material: their bodies or, as Helmuth Plessner aptly put it, 'the material of one's own existence'."16 Theatrologist Patrice Pavis shares a similar understanding of the concept of performance, whereby he bases himself on Irvin Goffman's theory. He argues that "one can certainly imagine a puppet theatre or theatre of objects, but we know that the 'performance' has been prepared by humans and not - in theory! - by animals or machines that have themselves created the mise en scène!"17 Another characteristics is mentioned by Rose Lee Goldberg in the third edition of her book in which she deliberates the $21^{\text {st }}$ century practice. "Artists around the globe turning to performance as a medium for articulating 'difference' of their own cultures and ethniticies and for entering the larger discourse of international culture in our highly mediated times." 18

It follows from the above citations that theory understands performance art as a medium in which artists most often use their own (human) body (or human bodies) and employ their peculiar subjectivity (i.e. a human performer's or human performers' subjectivity). If performance art gives prominence to diverse cultures, then it does so exclusively with respect to human cultures.

However, Chaudhuri's innovative article raises a fundamental question. If in theatre and in performance art the figure of the human as creator, maker, is not only the creator, contractor, protagonist, performer of the work itself or someone who presents and represents the work per se, but also someone who perceives the work, do these media even have the possibility to depart from anthropocentrism? A possible way out could be connecting the theatre and performance art with posthumanism.

\footnotetext{
${ }^{12}$ READ, A. Cit. ibid., p. 28.

${ }^{13}$ HOŘÍNEK, Z. Drama, divadlo, divák. [3 ${ }^{\text {rd }}$ edition]. Brno : JAMU, 2008, p. 72

${ }^{14}$ GOLDBERG, R. Performance Art. From Futurism to the Present. [ $3^{\text {rd }}$ edition]. London : Thames \& Hudson, 2011, p. 9.

${ }^{15}$ Ibid., p. 9.

${ }^{16}$ FISCHER-LICHTE, E. The Transformative Power of Performance. New York : Routledge, 2008, p. 76.

${ }^{17}$ PAVIS, P. The Routledge Dictionary of Contemporary Theatre and Performance. London, New York : Routledge, 2016, p. 158.

${ }^{18}$ GOLDBERG, R. Performance Art. From Futurism to the Present, p. 9.
} 


\section{Posthumanism and the Posthuman}

Since the second half of the $20^{\text {th }}$ century, there has been a debate in environmental ethics that reflects on the issues of human and non-human perspectives. They are outlined in the book Etika a príroda [Ethics and Nature] by the environmental philosopher Marie Skýbová. The opponents of the possible decentralisation of human perception argue that non-anthropocentrism is impossible. They base themselves on three main arguments. Typically, problems can only be perceived from a human point of view because it is impossible to physically step outside oneself, to become someone else, and to understand other person's experience. Further, it is claimed that non-anthropocentrism is unnatural - ethics is only given to man, without man ethics would not exist. ${ }^{19}$ Finally, non-anthropocentrism is dangerous, as it would require giving up human categories, such as differentiation between good and evil which may bear unexpected consequences and lead to the prioritisation of other species (at the expense of humanity) and even to the hostility to the Homo sapiens species. ${ }^{20}$

In other parts of the book, Skýbová refutes the above assertions and presents the opinions of philosophers Paul W. Taylor and John Seed. Taylor did not base himself on ethical standards but rather on the methods of modern science. He argues that stepping out of the human's egotistic perspective requires distancing, maximum objectivity, intellectual separation, and emotional neutrality. Conversely, John Seed rejects emotional neutrality, he writes about seeking a new opportunity for experiencing a profound change in consciousness, which disrupts alienation from nature. ${ }^{21}$ Whether it be Taylor's more rational position or Seed's deliberation on the change of consciousness, they both accentuate human capacity of imagination and thanks to it, the possibility to identify oneself with the interest of other human and non-human beings.

The school of thought called posthumanism is consistent with these propositions on other than anthropocentrist worldview which has been taking shape since the 1990s. Posthumanism is based on various critical positions toward the traditional understanding of the world. It links up with resistance represented by e.g. feminist studies seeking to transcend the dichotomous thinking of traditional Western philosophy and to newly formulate the concepts of reason, rationality, objectivity, as well as the entire cognitive process. ${ }^{22}$ Posthumanism does not have a uniform definition and it is best identified by what it builds on and by what it stands up against. According to media theoretist Jay David Bolter it continues the tradition of the critical reactions of postructuralism and postmodernism, "to what are perceived as totalizing practices and rhetorics of the modern era. In each case, the reaction was an attempt to subvert claims to unity, simplicity, or universality." ${ }^{23}$ Posthumanism stands in opposition to

${ }^{19}$ SKOLIMOWSKI, H. Cit. according to SKÝBOVÁ, M. Etika a př́roda. Hradec Králové : Pavel Mervart, 2011, p. 45.

${ }^{20}$ Ibid., p. 44

${ }^{21}$ Ibid., p. $97-110$.

${ }^{22}$ See FARKAŠOVÁ, E. Spory o rozum/racionalitu (diskusie v súčasnej feministickej filozofii). In Hodnotové aspekty súčasného sveta. Bratislava : Iris, 2003, p. 51.

${ }^{23}$ BOLTER, D. J. Posthumanism. In The International Encyclopedia of Communication Theory and Philosophy. Oxford : Willey Blackwell, 2016, p. 2. [online]. [cit. 21 July 2020]. Available at: https://onlinelibrary.wiley. com/doi/pdf/10.1002/9781118766804.wbiect220. 
the ideas of humanism which continues to be understood as the major western narrative that has spread across the globe. He points out that humanistic ideals fail because they are based on a position defined by a certain group. Art theorist Hana Janečková deliberates: "Humanism as a Eurocentric cultural specificity of the white man has become a standard and a worldview inevitably leading to sexualisation (of women), racial division (those indigenous people), and othering (animal, planets, the Earth)." ${ }^{24}$ The white man dominates the world since power is concentrated in his hands (economic, military, political, material) and sets social discourse, while deepening the collective idea of a united humanity (following the idea of a united human - an "anthropos") that heads for continuous progress. Although it employs the concept of human dignity of every individual, a lot of human and non-human beings are singled out or they are overriden (which follows from the very essence of its anthropocentric, Europocentric, phallocentric, etc. orientation).$^{25}$ Hence, put in the words of a prominent female philosopher of posthumanism Francesca Ferrando: "Posthumanism may arise once the need for such a 'vengeance' has been fulfilled, and the voices of the subjectivities which have been historically reduced to the realm of the 'Other,' have been acknowledged. Posthumanism is inextricably related to the studies of the differences, referring to the fields of research which developed out of the deconstruction of the 'neutral subject' of Western onto-epistemologies." 26 This is why the above school of thought deals with the deconstruction or rather the reconstruction of the very concept of the human.

To give an example in his monograph on postuhumanism, philosopher Cary Wolfe refers to modern man as a prosthetic being ${ }^{27}$; the author of a posthumanist manifesto Robert Pepperell writes about fuzzy humans ${ }^{28}$. In his Philosophical Posthumanism Ferrando argues that one should be using the word "humanising" rather than the "human" (man) which means that: "By presenting the human as a verb (...) we aim to emphasize its performative dynamics and its potentials, which may spark different outcomes. (...) I am, in my embodied human experience, and, in relation to others." 29

All the authors quoted above unanimously claim that what we are inclined to denote as "we," "is in fact a multiplicity of relations between 'us' and 'not us', 'inside' and 'outside', organic and non-organic, things 'present' and things 'absent'." 30 Philosophical posthumanism, by reducing reductivities, by the decentralisation of a human entity and subsequently other categories related to it, disrupts traditional dualistic framing of the Self versus the Other, subject/object, live/non-live, man/ani-

${ }^{24}$ JANEČKOVÁ, H. Knihovnička: Posthumanismus jako horizont naděje? In Artalk.cz, 8 December 2017. [online]. [cit. 26 January 2020]. Available at: https://artalk.cz/2017/12/08/knihovnicka-posthumanismus-jakohorizont-nadeje/.

${ }^{25}$ See FERRANDO, F. Philosophical Posthumanism. London, New York : Bloomsbury, 2019, p. 24.

${ }^{26}$ Ibid., p. 25.

${ }^{27}$ Indeed, the human is itself a prosthetic being, who from day one is constituted as human by its coevolution with and constitution by external archival technologies of various kinds - including language itself as the first archive and prosthesis. WOLFE, C. What is Posthumanism. Minneapolis, London: The University of Minnesota Press, 2010, p. 295.

${ }^{28}$ See PEPPEREL, R. The Posthuman Condition. Bristol : Intellect Books, 1990, p. 20.

${ }^{29}$ FERRANDO, F. Philosophical Posthumanism, p. 85.

${ }^{30}$ See WOLFE, C. Posthumanism. In BRAIDOTTI, R., HLAVAJOVA, M. (ed.). Posthuman Glossary. London : Bloomsbury Academic, 2018, p. 358. 
mal, man/robot, male/female, physical/virtual, meat/machine, local/foreigner, nor$\mathrm{mal} /$ pathological ${ }^{31}$. For this reason, Ferrando defines philosophical posthumanism as a discourse that builds on three main ideas: post-humanism, post-anthropocentrism, and post-dualism. ${ }^{32}$

\section{Posthumanism and Theatre}

The concept of posthumanism becomes increasingly commonplace in aesthetics, fine arts, practice, art theory, and even in anthropocentrically oriented media, such as theatre and performance art. (Even a text regarded as the heralding of posthumanism by the philosopher Ihab Hassan Prometheus as Performer: Toward and Posthumanist Culture ${ }^{33}$ formally belongs to dramatic writing). Art theorist Mark McGurl in his essay The Posthuman Comedy notes that the trace of the posthuman is easier identified in the works that good taste has always held in contempt. He gives examples of science fiction, horror literature, and the Gothic novel..$^{34}$ In the work The Cambridge Companion to Literature and the Posthuman ${ }^{35}$ one may find multiple references to the works of the above genres manifesting the characteristics of posthumanism in diverse ways. The book analyses comics which were popular hypertext books towards the close of the millennium and it features a separate chapter on cinematics. However, when it comes to theatre and performing arts, the book only analyses the works by Christopher Marlow Doctor Faustus and Shakespeare The Tempest, ${ }^{36}$ while mention is also made of Samuel Beckett.

There are probably several reasons why the book does not give a more prominent representation to drama and theatre. In addition to anthropocentric orientation, it is probably also because of the fleeting nature of a theatre production or of the works of performance art. However, it also applies to theatre that the works that exist outside the mainstream are more inclined to display the characteristics of posthumanism. In literature, they rank among marginal genres and subgenres, in theatre and performing arts, they are among the works from a group referred to as postdramatic theatre. These works, among other things, are characterised by what is unique to comics, hypertext books, and also to bioart, namely, by their interdisciplinary nature. It is interdisciplinarity that complicates their classification into clear categories such as theatre and performance art and raises the question about the arts and humanities that should actually examine them as first. For example, Czech theatrologist and media theorist Jan Motal underscores the importance of the opening of theatre studies

\footnotetext{
${ }^{31}$ See FERRANDO, F. Philosophical Posthumanism, p. 54.

${ }^{32}$ Ibid.

${ }^{33}$ HASSAN, I. Prometheus as Performer: Toward a Posthumanist Culture? In The Georgia Review, 1977, Vol. 31, Issue 4, pp. $830-850$.

${ }^{34}$ See MCGURL, M. The Posthuman Comedy. In Critical Inquiry, 2012, Vol. 38, Issue 3, p. 535.

${ }^{35}$ CLARKE, B., ROSSINI, M. (ed.). The Cambridge Companion to Literature and the Posthuman. London : Cambridge University Press, 2017, p. 231.

${ }^{36}$ As claimed by Kevin LaGrandeur: Marlowe and Shakespeare point out the fact that "humans have never really been autonomous entities, but rather they have always been intimately interdependent upon their environments and tools. (...) For instance, the intelligent-servant networks created by Shakespeare's Prospero in The Tempest and Marlowe's protagonist in Dr. Faustus provide their respective makers with not only an enhancement, but also a distribution of their agency." See LaGrandeur, K. In CLARKE, B., ROSSINI, M. (ed.). The Cambridge Companion to Literature and the Posthuman, p. 16.
} 
to other disciplines, not only to the humanities (which has always belonged to the theatrological practice in Central Europe), but also to biological sciences or medical sciences (for example, to ethology or neuroscience), so that current theoretical concepts may be reconsidered through these sciences. For instance, through neuroscientific analysis, Motal questions the starting points of Joachim Fiebach's theory of theatricality. Theatricality perceives theatre as a cultural model that can be applied to various forms of social events. But Motal is convinced that when considering the methods of Theatre Studies, it should be just the opposite. He argues "we should reverse our point of view and see theatre as a phenomenon explainable by other concepts and theories (transgressing the field boundaries). The specific theatre mimetic behavior (involving professional actors and audience) should be understood as an instance of mental strategies and cognitive faculties, which makes us able to live in a community." ${ }^{37}$ He further suggests that catharsis, one of the key concepts in the analysis of theatre, is presently distorted by an array of anthropocentric and Eurocentric interpretations. Motal, by citing William F. Trench, calls for a return to an ecological understanding of this concept (based on the teachings of Theofrast), which will enable to: "a) show that even in 'noble' artistic forms we are first and foremost animals (and part of nature); and b) teach us how to use the (shared) faculties to achieve interspecies understanding." 38 Because of that "non-anthropocentric and non-ethnocentric theatre studies can contribute to solving our prevailing environmental crisis." 39

\section{Non-anthropocentrism in Posthumanism}

In order to encourage the extension of the field of interest of Theatre Studies to works that in a certain framework represent non-anthropocentrism and at the same time boost the potential to deliberate the different levels (historical, political, and material) of human interconnection with non-human nature but also connection between non-human beings and non-human beings, philosophical theories and the being interpretation theories which belong to posthumanist studies and to the sphere of posthuman ethics, could be put to use.

Various conceptions are based on natural sciences - physics, ecology, biology, chemistry, and others. For example, a frequently quoted is the theory of agential realism by the theoretical physicist Karen Barad, inspired by the theories of the physicist Niels Bohr, which turns to matter and the relationships within it. This theory does not understand the world as divided into categories meticulously named by man but rather as a "dynamic process of intra-activity and materialization in the enactment of determinate causal structures with determinate boundaries, properties, meanings, and patterns of marks on bodies." ${ }^{40}$ Agential realism does not perceive the subject as a clear and definable category, there is no agent or an actant capable of independent

\footnotetext{
${ }^{37}$ MOTAL, J. Behind the Curtain of Phylogeny: From Theatrical Anthropocentrism to Interspecies Appreciation In The Slovak Theatre, 2019, Vol. 67, Issue 3, p. 251. DOI 10.31577/sd-2019-0014.

${ }^{38}$ Ibid., p. 253.

${ }^{39}$ Ibid., p. 251.

${ }^{40}$ BARAD, K. Meeting the Universe Halfway: Quantum Physics and the Entanglement of Matter and Meaning. Durham : Duke University Press, 2007, p. 140.
} 
existence, thinking, and action. It is made up of an "ongoing flow of agency through which 'part' of the world makes itself differentially intelligible to another 'part' of the world and through which causal structures are stabilized and destabilized does not take place in space and time but happens in the making of spacetime itself." 41

Jane Bennett, thinker of New Materialism, ties into the work of Karen Barad to explore the political dimension of matter and things and urges "to devise new procedures, technologies, and regimes of perception that enable us to consult nonhumans more closely, or to listen and respond more carefully to their outbreaks, objections, testimonies, and propositions. For these offerings are profoundly important to the health of the political ecologies to which we belong." ${ }^{42}$ By doing so, Bennett indirectly sets up the space for one of the non-anthropocentric art agendas and today, many artists representing all forms of art rise to this challenge.

\section{Postdramatic can be Posthumanist}

In the context of drama, theatre play, and performance art, this applies in particular to artists who would fall within the framework of the post-dramatic theatre of the German theorist Hans-Thies Lehmann. Several theorists, such as Wallace Heim, Bonnie Marranca, Magda Romanska, Carl Lavery, Louise LePage, Louis van den Hengel, find connections between the non-anthropocentric understanding of the world and postdramatic theatre. The connection between Lehmann's concept and the origins of posthumanism is also obvious. Postdramatic theatre does not have a single definition. Rather, it is an umbrella term for various, often hybrid, theatrical forms to which all or some of the following assertions apply.

In postdramatic theatre, the text may be the main element of a theatre production, but it can also be absent. If the text is part of the work, it usually has a specific structure, it does not follow dramatic conventions (there are no dramatic characters, dramatic space, dramatic plot, etc.). In post-dramatic theatre, a situation determined by spatial, visual, and audio signs takes over instead of a dramatic situation. Instead of the actor, there is a performer who does not have to imitate or perform mimesis. The perfomer does not render a concrete character or type, but rather is defined by the intersection of different energies. Emphasis is placed on the authenticity of the performer's being, on chorality (that is, the relationships between the bodies of performers and collective action). A work of postdramatic theatre represents a direct communication process between the stage and the auditorium, without the pursuit for illusiveness. In postdramatic theatre, instead of simulating an emotion, an emotion based on an individual or collective position takes over. ${ }^{43}$

Postdramatic theatre and its forms share a diverse range of common values with posthumanism, such as non-hierarchical structure, chaotic nature, and an unpredictable structure, dynamism, openness, collaborative spirit, emphasis on the process of becoming, i.e. on performativity. In addition, it shares the potential for variability and

\footnotetext{
${ }^{41}$ Ibid.

${ }^{42}$ See BENNETT, J. Vibrant Matter A Political Ecology of Things. Durham, London : Duke University Press, 2010, p. 108.

${ }^{43}$ See PAVIS, P. The Routledge Dictionary of Performance and Contemporary Theatre. London : Routledge, 2016, pp. 188 - 195 and LEHMANN, H. T. Postdramatic Theatre. London : Routledge, 2006.
} 
a creative potential of chance and hybridisation with other forms of art, technologies, and media. ${ }^{44}$ Theatrologist Wallace Heim also emphasises important links between posthumanism and postdramatic theatre: "Lehmann does remind us of the need for theatre production not to represent the facts, but to present, rather than spell out, a situation or human condition. The postdramatic, for Lehmann, may make evident more of the hidden dynamics of conflicts (...). Lehmann finds that the postdramatic may be a reflection of, rather than a resistance to, contemporary social structures." ${ }^{45}$

\section{Non-anthropocentrism in Postdramatic Theatre}

In the chapter "Panorama of Postdramatic Theatre" Lehmann poses the question of non-anthropocentric or post-anthropocentric stage, and even points out its significance when it comes to the accentuation of ecological issues. He also deals with several forms of post-anthropocentric theatre, finding starting points in the first half of the $20^{\text {th }}$ century, and the chapter was a source of inspiration to several theatre professionals. In her book The Death of Character, chapter "Another Version of Pastoral", Elinor Fuchs analysed this in greater detail. The authoress based herself on the term landscape play which was defined by Gertrude Stein. The landscape metaphor means that the reader moves freely through the work, not along the marked paths of universal interpretations. ${ }^{46}$ Just as natural philosophies emphasise the equal status of the human and the natural (although it is an array of diverse diversities), Stein emphasises "a defocalization and equal status for all parts, a renunciation of teleological time, and the dominance of an 'atmosphere' above dramatic and narrative forms of progression." ${ }^{47}$ Stein created "the principle of a 'continuous present', of syntactic and verbal concatenations that mark time seemingly statically (similar to the later 'minimal music') but in reality continuously create new accents in subtle variations and loops." 48 Stein's landscape metaphor accentuates the fact that while drama is composed of (democratically arrayed) things/details (particulars) it could not exist without them. A human subject is also a thing/detail (particular), and therefore it is decentralised according to Stein. It is a component part of an extensive system and relations distribution, and the system and relations are central to her works, i.e. "a thing held full in-view the whole time. "49 According to Lehmann, these aesthetic points of departure illusorily allude to an alternative to the anthropocentric ideal of the subjugation of nature: "When human bodies join with objects, animals and energy lines into a single reality (...), theatre makes it possible to imagine a reality other than that of man dominating nature." 50

${ }^{44}$ These posthumanism characteristics are aptly pinned down by Francesca Ferrando in her article Towards A Posthumanist Methodology. A Statement. See FERRANDO, F. Towards A Posthumanist Methodology. A Statement. In FRAME, [online], 2012, Vol. 25, Issue 1, pp. 9 - 17. [online]. [cit. 25 July 2020]. Available at: http://www.tijdschriftframe.nl/wp-content/uploads/2015/05/Frame-25_01-Ferrando.pdf.

${ }^{45}$ HEIM, W. Theatre, Conflict and Nature. In Green Letters, 2016, Vol. 20, Issue 3, p. 300.

${ }^{46}$ See FUCHS, E. Another Version of Pastoral. In FUCHS, E. The Death of Character. Perspectives on Theater after Modernism. Bloomington, Indianapolis : Indiana University Press, 1996, p. 92.

${ }^{47}$ LEHMANN, H. T. Postdramatic Theatre, p. 63.

${ }^{48}$ Ibid.

${ }^{49}$ Ibid.

${ }^{50}$ Ibid., p. 81. 
Among the $20^{\text {th }}$ century works associated by Fuchs with the concept of landscape play are, in addition to Gertrude Stein's dramas, also some plays by Maurice Maeterlinck, Samuel Beckett, Heiner Müller, productions by Robert Wilson, Reza Abdoh, Meredith Monk, Richard Foreman, and others. Their works are often referred to as postmodern. They operate in non-traditional frames of time and space, rejecting the gradation of rhythm, going against the logic of classical narration, relying more on a continuous, simultaneous non-dramatic narration. At the same time, they redefine or give a new definition to the relationships between individual actors who enter the whole and do not by far represent just human individuals. ${ }^{51}$

\section{Postdramatic Theatre and Posthumanism}

The perspective applied in this study is a continuation of the line suggested by Fuchs. She writes about postmodern artists, pointing to their "longs for a vanishing natural world, and sometimes a vanished natural world, existing before history, before culture." 52

The presented text focuses on the works of drama, theatre, and performing arts associated with posthumanism, as they confront anthropocentrism in various ways or engage approaches that offer non-anthropocentric and post-anthropocentric knowledge. Furthermore, just like posthumanism, these works open their "inquiry to non-human life: from animals to artificial intelligence, from aliens to other forms of hypothetical entities related to the physics notion of a multiverse ${ }^{\prime \prime 53}$ and alongside that posthumanism "questions biocentrism and the concept of life itself, blurring the boundaries between the animate and the inanimate, in a quantum approach to the physics of existence." 54

As mentioned with Jane Bennett, these works have the potential "to devise new procedures, technologies, and regimes of perception that enable us to consult nonhumans more closely, or to listen and respond more carefully to their outbreaks, objections, testimonies, and propositions (....)." ${ }^{55}$ One should also include in here drama, theatre, and performing art, same as multiform and multi-genre works of art for various reasons falling under Lehmann's category of postdramatic theatre or works that transgress this framework and converge on intermedia art. To give examples:

- Works that focus on the co-existence of man and non-human beings. (Estado Vegetal, 2019, Chilean authoress Manuela Infante; Rain dance, 2009 and Prales [Deep Forest], 2012, the Prague group Handa Gote; Monstrous Nature, 2011, Marcel Levi and Lucía Russo; The Soft Act of Killing, 2019, Agata Siniarska).

- Works that engage in a targeted interaction with non-human beings in order to review, rethink, and establish more balanced relations between man and these beings, i.e. with a purpose other than using them as a tool serving the needs of the arts (Jenseits der Natur - Volksherrschaft im Garten, Club Real; The Artificial Nature

${ }^{51}$ See FUCHS, E. Another Version of Pastoral, p. 107.

${ }^{52} \mathrm{Ibid}$.

${ }^{53}$ FERRANDO, F. Towards a Posthumanist Methodology. A Statement, p. 11.

${ }^{54}$ Ibid.

${ }^{55}$ See BENNETT, J. Vibrant Matter: A Political Ecology of Things. Durham, London : Duke University Press, 2010, p. 108. 
Project by Mette Ingvartsen, 2012; Some Significance, 2017 and Living Matters, 2019, Eva Meyer Keller; I Hunt Nature and Nature Hunts Me, 2014, Maja Smrekar).

- Works targeted at the non-human recipient (Performances for Pets, 2014, Krõõt Juurak and Alex Bailey; A Performance with an Ocean View (and a Dog/for a Dog), Tuija Kokkonen, 2012).

- Outputs of diverse artistic forms in which, under certain circumstances, a non-human entity becomes an actor in the work of art, an improvising performer rather than an "actor" performing the role assigned to him/her (Sheep Pig Goat, 2017, Fevered Sleep; Hybrid Family, 2016, Maja Smrekar; Webs of At-tent(s)ion, 2018, Tomás Saraceno).

The works of art mentioned above to illustrate individual categories are predominantly focused on the groups of non-human nature, i.e. on non-human, which do not belong to technology or artificial intelligence group (in terms of the established understanding of these concepts). Although the philosophy of posthumanism (as developed by Ferrando) claims that "technology should be rethought not in separation from the environment, but as part of the environment" ${ }^{\prime 56}$ and points out an integral co-evolution of human cultures and technologies, at the same time, it contains several critical notes on technology. Ferrando cites Heidegger's essay on technologies: "The threat to man does not come in the first instance from the potentially lethal machines and apparatus of technology. The actual threat has already affected man in his essence." 57 Technologies, even those detached from human control, are a product of human invention and a tool. They are often created for a utilitarian purpose, e.g. to overcome obstacles that pose a threat to the human, to increase social equality, but also to enable speedier production, greater control or gain dominance over a certain group. In addition, the technologies themselves originate directly from natural materials and their terrestrial resources, producing various types of waste (material and digital), which has an impact on human health and the environment. Their position in posthumanist discourse is therefore complex and problematic.

Further reflection on these works could shed light on the various strategies, tools, and artistic means that theatre and performers use in the field of performance art to transcend their anthropocentric position. To what extent do they apply established artistic styles and what makes their practices different from the established ones? Are they looking for any new ways of expression? A separate topic is also critical thinking about these creations and the approaches used. Even Francesca Ferrando who paves the way for the philosophy of posthumanism, suggests that it "should be performed in a way which expresses its full meanings and ambitious purposes not only by paying lip service to a new fashionable academic trend, but through a research which finds in the difference its theoretical kernel." ${ }^{58}$ This is also related to the fact that this discourse truly pursues great ambitions, i.e.: "to acknowledge the whole human experience in order to be receptive to the non-human and be open to unknown possibilities." 59 For the time being, the reflections of drama, theatre play, and performance art that offer themes, create poetics, and communicate knowledge in which

\footnotetext{
${ }^{56}$ FERRANDO, F. Philosophical Posthumanism, p. 118.

${ }^{57}$ HEIDEGGER, M. Cit. according to FERRANDO, F. Philosophical Posthumanism, p. 118.

${ }^{58}$ FERRANDO, F. Towards a Posthumanist Methodology. A Statement, p. 11.

${ }^{59}$ Ibid.
} 
humans and their society do not constitute its centre, call for a cautious, sober, and critical rather than enthusiastic approach.

\section{Translated by Mária Švecová}

\section{LITERATURE}

BARAD, Karen. Meeting the Universe Halfway: Quantum Physics and the Entanglement of Matter and Meaning. Durham : Duke University Press, 2007. 544 p. ISBN 978-0-8223-8812-8.

BENNETT, Jane. Vibrant Matter: A Political Ecology of Things. Durham, London : Duke University Press, 2010. 200 p. ISBN 978-0-8223-4633-3.

BOLTER, David Jay. Posthumanism. In The International Encyclopedia of CommunicationTheory and Philosophy. Oxford : Willey Blackwell, 2016, p. 2. [online]. [cit. 21 July 2020]. Available at: https://onlinelibrary.wiley.com/doi/pdf/10.1002/9781118766804.wbiect220.

CLARKE, Bruce, ROSSINI, Manuela (eds.). The Cambridge Companion to Literature and the Posthuman. London : Cambridge University Press, 2017. 272 p. ISBN 978-1107450615.

FERRANDO, Francesca. Philosophical Posthumanism. London, New York : Bloomsbury, 2019. 296 p. ISBN 978-1-3500-5949-8.

FERRANDO, Francesca. Towards a Posthumanist Methodology. A Statement. In FRAME, 2012, Vol. 25, Issue 1, 2012, pp. 9 - 17. [online]. [cit. 25 July 2020]. Available at: http://www.tijdschriftframe.nl/wp-content/uploads/2015/05/Frame-25_01-Ferrando.pdf.

FARKAŠOVÁ, Etela. Spory o rozum/racionalitu (diskusie v súčasnej feministickej filozofii). In Hodnotové aspekty súčasného sveta. Bratislava : Iris, 2003, pp. 51 - 57. ISBN 9788089018574.

FISCHER-LICHTE, Erika. The Transformative Power of Performance. New York : Routledge, 2008. 240 p. ISBN 978-0-203-89498-9.

FUCHS, Elinor. Another Version of Pastoral. In FUCHS, Elinor. The Death of Character. Perspectives on Theater after Modernism. Bloomington, Indianapolis : Indiana University Press, 1996. 224 p. ISBN 978-0253210081.

GOLDBERG, RoseLee. Performance Art. From Futurism to the Present. [3rd edition]. London : Thames \& Hudson, 2011. 256 p. ISBN 978-0500204047.

HASSAN, I. Prometheus as Performer: Toward a Poshumanist Culture? In The Georgia Review, Vol. 31, Issue 4, 1977, pp. 830 - 850. ISSN 0016-8386.

HEIM, Wallace. Theatre, Conflict and Nature. In Green Letters, 2016, Vol. 20, Issue 3, pp. 290 303. ISSN 1468-8417.

HOŘÍNEK, Zdeněk. Drama, divadlo, divák. [3rd edition]. Brno : JAMU, 2012, 204 p. ISBN 9788074600265.

CHAUDHURI, Una. "There Must Be a Lot of Fish in That Lake" Toward an Ecological Theater. In Theater, Vol. 25, Issue 1, 1994, pp. 23 - 31. ISSN 0161-0775.

JANEČKOVÁ, Hana. Knihovnička: Posthumanismus jako horizont naděje? In Artalk.cz [online]. 8. 12. 2017. [cit. 26 January 2020]. Available at: https://artalk.cz/2017/12/08/knihovnicka-posthumanismus-jako-horizont-nadeje/. ISSN 1805-6989.

LEHMANN, Hans-Thies. Postdramatic Theatre. London : Routledge, 2006. 226 p. ISBN 9780415268127.

MALINA, Ján. et al. Antropologický slovník. BRNO : Akademické nakladatelství CERM, 2009. 304 p. ISBN 9788072045600.

MCGURL, Mark. The Posthuman Comedy. In Critical Inquiry, Vol. 38, Issue 3, 2012, pp. 533 553. ISSN 1539-7858.

MINTEER, Ben. A. Anthropocentrism. In CALLICOTT, J. Baird, FRODEMAN, Robert (eds.). Encyclopedia of Environmental Ethics and Philosophy (Vol. 1). USA : Macmillan Reference, 2009, pp. 58 - 62. ISBN 978-0028661377. 
MOTAL, Jan. Behind the Curtain of Phylogeny: From Theatrical Anthropocentrism to Interspecies Appreciation. In The Slovak Theatre, 2019, Vol. 67, Issue 3, pp. 240 - 257. ISSN 0037-699X. DOI 10.31577/sd-2019-0014.

O'NEILL, Onora. Environmental Values, Anthropocentrism and Speciesism. In BOYLAN, M. Environmental Ethics. Oxford: WILEY Blackwell, pp. 123 -124. ISBN 978-1118494721.

PAVIS, Patrice. The Routledge Dictionary of Contemporary Theatre and Performance. London, New York : Routledge, 2016. 312 p. ISBN 9781138854352.

PEPPEREL, Robert. The Posthuman Condition. Bristol : Intellect Books, 1990. 224 p. ISBN 9781841502908.

SKÝBOVÁ, Marie. Etika a př́roda. Hradec Králové : Pavel Mervart, 2011. 196 p. ISBN 978-8087378-80-9.

STOERMER, Eugene, CRUTZEN, Paul, J. The 'Anthropocene'. In Global Change Newsletter, 2000, Issue 41, pp. 17- 18. ISSN 0284-5865.

WOLFE, Cary. Posthumanism. In BRAIDOTTI, Rosi, HLAVAJOVA, Maria (eds.). Posthuman Glossary. London : Bloomsbury Academic, 2018. 576 p. ISBN 9781350030237.

WOLFE, Cary. What is Posthumanism. Minneapolis, London : The University of Minnesota Press, 2010. 392 p. ISBN 978-0-8166-6615-7.

WUKETITS, Franz M. Př́rodní katastrofa jménem člověk. Praha : Granit, 2006. 207 p. ISBN 8072960474.

ZENG, Fanren. Introduction to Ecological Aesthetics. Singapore : Springer Nature, 2019. 370 p. ISBN 9811389837.

Milo Juráni

Divadelná fakulta

Vysoká škola múzických umení

Zochova 1

81301 Bratislava

Slovakia

e-mail: jurani.miloslav@gmail.com 